\title{
Role of kairomones in host location of the pennellid copepod parasite, Lernaeocera branchialis (L. 1767)
}

\author{
A. J. BROOKER ${ }^{1}$, A. P. SHINN ${ }^{1}, \mathrm{~S} . \mathrm{SOUISSI}^{2}$ and J. E. BRON ${ }^{1}$ \\ ${ }^{1}$ Institute of Aquaculture, University of Stirling, Stirling FK9 4LA, UK \\ ${ }^{2}$ Université Lille 1, Sciences et Technologies, UMR CNRS 8187 LOG, Station Marine, 28 Avenue Foch, F-62930 \\ Wimereux, France
}

(Received 16 August 2012; revised 9 November 2012; accepted 9 November 2012; first published online 1 February 2013)

SUMMARY

The life cycle of the parasitic copepod Lernaeocera branchialis involves 2 hosts, typically a pleuronectiform host upon which development of larvae and mating of adults occurs and a subsequent gadoid host, upon which the adult female feeds and reproduces. Both the copepodid and adult female stages must therefore locate and identify a suitable host to continue the life cycle. Several mechanisms are potentially involved in locating a host and ensuring its suitability for infection. These may include mechano-reception to detect host movement and chemo-reception to recognize host-associated chemical cues, or kairomones. The aim of this study was to identify the role of kairomones in host location by adult L. branchialis, by analysing their behaviour in response to fish-derived chemicals. Experiments demonstrated that water conditioned by immersion of whiting, Merlangius merlangus, elicited host-seeking behaviour in L. branchialis, whereas cod- (Gadus morhua) conditioned water did not. Lernaeocera branchialis are considered a genetically homogeneous population infecting a range of gadoids. However, their differential response to whiting- and cod-derived chemicals in this study suggests that either there are genetically determined subspecies of $L$. branchialis or there is some form of environmental pre-conditioning that allows the parasite to preferentially recognize the host species from which it originated.

Key words: Lernaeocera branchialis, kairomone, copepod, parasite, host location, behaviour, semiochemical, chemoreception.

\section{INTRODUCTION}

Lernaeocera branchialis (L. 1767) is a parasitic copepod, the mated adult female stage of which impacts a range of gadoids by attaching to the gills and feeding on the blood of its host, causing serious pathogenic effects. The life cycle of L. branchialis is complex as it involves 2 hosts. The initial host is usually a pleuronectiform or other demersal fish (Brooker et al. 2007), whereas the usual host infected by the mated adult female is a gadoid fish, with cod, Gadus morhua, whiting, Merlangius merlangus, haddock, Melanogrammus aeglefinus and pollack, Pollachius pollachius being the most common hosts (Kabata, 1979). Although the life cycle of L. branchialis has been well documented (Scott, 1901; Sproston, 1942; Capart, 1947, 1948; Brooker et al. 2007), the method of host location remains unknown. Both the copepodid and the adult female stages of L. branchialis must locate and identify a suitable fish host to continue the life cycle. It is likely that specific mechanisms are employed to initially locate a host and then to ensure that it is suitable. The adult female spends 3-8 days on the initial host, depending on

* Corresponding author: Institute of Aquaculture, University of Stirling, Stirling FK9 4LA, UK. Tel: $+44(0) 1786$ 467876. Fax: + $44(0) 1786$ 472133. E-mail: ajb3@stir.ac.uk the number of times a female is inseminated (Anstensrud, 1990), suggesting that insemination by a male is the trigger for the female to leave the first host to search for the second host. If a suitable host is not located before the energy reserves of the parasite are depleted, it will die, although there have been instances where a metamorphosed adult female has been found to infect the nominal first host (Schuurmans Stekhoven, 1936; Begg and Bruno, 1999), which may be a decision made by the parasite in the absence of the optimal second host.

It is likely that there are several mechanisms involved in host location and these may include mechano-reception to detect host movement and chemo-reception to recognize host-associated chemical cues. The parasite may also use other physical phenomena in the water column, such as thermoclines and haloclines, to search for likely concentrations of fish hosts. In planktonic organisms, kairomones are known to play a number of roles including prey detection, predator avoidance and host location by parasites. The role of kairomones in plankton was first demonstrated in rotifers (De Beuchamp, 1952) and has since been studied extensively. The use of chemo-reception for host location was originally demonstrated in caligids by Fraile et al. (1993), where mucus from sea bass, Dicentrarchus labrax, was shown to alter the behaviour of Caligus 
minimus Otto, 1821. More recently, the salmon louse Lepeophtheirus salmonis, Krøyer, 1837 has been shown to employ chemo-reception to recognize host-associated chemical cues (Devine et al. 2000). Lepeophtheirus salmonis demonstrate increased activity and positive rheotaxis when exposed to compounds originating from Atlantic salmon, Salmo salar, but not from turbot, Scophthalmus maximus Rafinesque 1810, demonstrating the use of kairomones for host location by L. salmonis as well as host recognition (Devine et al. 2000). Extraction of low molecular weight compounds from salmonconditioned water using solid-phase extraction techniques has shown that $L$. salmonis demonstrates a behavioural response and an electrophysiological response in their antennae to the chemicals isophorone and 1-octen-3-ol (Ingvarsdottir et al. 2002). As well as utilizing chemical cues for host location, L. salmonis has also been shown to use mechanoreception to detect host movement (Bron et al. 1993; Heuch and Karlsen, 1997) and, in pre-adult and adult stages, a pronounced shadow response to passing fish (J. Bron, personal observation).

The aim of this study was to identify the role of kairomones in host location by adult female L. branchialis by analysing the parasites' behavioural responses to a range of host-derived substances. This was investigated by the use of 2 experimental procedures: (a) response of the parasites in a Y-shaped choice chamber when provided with the option of clean seawater or seawater containing potential sources of kairomones derived from host and non-host fish species; (b) changes in the natural behaviour of the parasites observed in 3 dimensions, when presented with a similar range of potential sources of kairomones.

\section{MATERIALS AND METHODS}

\section{Collection of parasites, water and chemical cues}

Flounder, Platichthys flesus, infected with L. branchialis were sampled from the catches of commercial demersal trawlers working within the River Forth Estuary at Kincardine, Scotland $\left(56^{\circ} 02^{\prime} 53^{\prime \prime} \mathrm{N}, 3^{\circ} 40^{\prime}\right.$ $\left.59^{\prime \prime} \mathrm{W}\right)$. They were collected from the trawlers in dock and transported to the University of Stirling in large plastic bags containing seawater under aeration. The fish were maintained in $100 \mathrm{~L}$ static tanks at $10^{\circ} \mathrm{C}$ with a bio-filter $(6 \cdot 5 \mathrm{~L}$ Eheim canister) to maintain water quality and fed daily using a combination of frozen ragworm, Nereis virens (Seabait Ltd), and sinking trout pellets (Europa 15, Skretting). To collect pre-metamorphosed adult female L. branchia$l i s$, a $50 \mu \mathrm{m}$ mesh was placed over the filter intake pipe to prevent loss of free-swimming parasites and tank water was siphoned daily into an empty $100 \mathrm{~L}$ tank through a $50 \mu \mathrm{m}$ sieve to remove any adult L. branchialis that had left their host. The parasites were then washed into a $500 \mathrm{~mL}$ beaker with seawater and maintained at $10^{\circ} \mathrm{C}$ until required. Before each experiment, the gender of each parasite was visually checked to ensure that only females were used.

Clean seawater for use in the behaviour experiments was collected from the shore at East Wemyss, Fife, Scotland ( $\left.56^{\circ} 09^{\prime} 35^{\prime \prime} \mathrm{N}, 3^{\circ} 03^{\prime} 36^{\prime \prime} \mathrm{W}\right)$. Full salinity (35 Practical Salinity Units, PSU) was verified using a salinometer (Atago S/Mill, Japan) and the water was kept in a $400 \mathrm{~L}$ tank with aeration until required. This water was used for all behavioural experiments, including the production of the chemical cues to ensure consistency throughout the experiments.

Four species of fish were selected to test the response of L. branchialis to chemical cues: cod and whiting as second hosts; flounder as the first host; and brown trout (Salmo trutta) as a freshwater non-target species. Whiting, cod and flounder were sampled from the catches of commercial demersal trawlers, transported to the University of Stirling and maintained in tanks, as detailed previously, whereas juvenile brown trout were sampled from a commercial fishery near Stirling, Scotland $\left(56^{\circ} 04^{\prime} 20^{\prime \prime} \mathrm{N}, 3^{\circ}\right.$ $\left.57^{\prime} 04^{\prime \prime} \mathrm{W}\right)$. For each species of fish, 4 potential kairomone sources were collected: fish-conditioned water, mucus, flesh and feces, giving a total of 16 different cues plus a seawater control. For the 3 marine species, fish-conditioned water was prepared by maintaining live fish in seawater for $24 \mathrm{~h}$ at a ratio of $10 \mathrm{~g}$ fish per $1 \mathrm{~L}$ of water. Trout were kept in fresh water at the same ratio of fish:water and then the fish were removed before salt was added (Instant Ocean synthetic sea salt) to make full strength seawater (35 PSU). Mucus was collected from several freshly euthanized fish (anaesthetic overdose using 0.5-0.6 $\mathrm{ml} \mathrm{L}^{-1}$ 2-phenoxyethanol (Sigma-Aldrich) until cessation of respiratory activity, followed by a blow to the head to ensure brain death and rinsing in seawater to remove anaesthetic) by rinsing the fish with $100 \mathrm{~mm}$ ammonium bicarbonate (Ross et al. 2000) and then diluting the resulting liquid in $1 \mathrm{~L}$ of seawater. For the flesh cue source, $5 \mathrm{~g}$ of skin-free body muscle was homogenized and added to $1 \mathrm{~L}$ of seawater. Faeces were collected by maintaining fish in a $30 \mathrm{~L}$ tank for $24 \mathrm{~h}$ and then filtering the water to remove the feces before adding them to $1 \mathrm{~L}$ of seawater. Once the study was complete, all experimental fish were euthanized using an overdose of anaesthetic $\left(0 \cdot 5-0.6 \mathrm{ml} \mathrm{L} \mathrm{L}^{-1}\right.$ 2-phenoxyethanol (Sigma-Aldrich) until respiratory activity ceased, followed by a blow to the head to ensure brain death. Before commencing, all experiments were approved by the University of Stirling Ethics committee. The Institute of Aquaculture, University of Stirling is licensed to carry out animal experiments under a certificate of designation according to the Animals (Scientific Procedures) Act 1986 and regulated by the UK Home Office. 


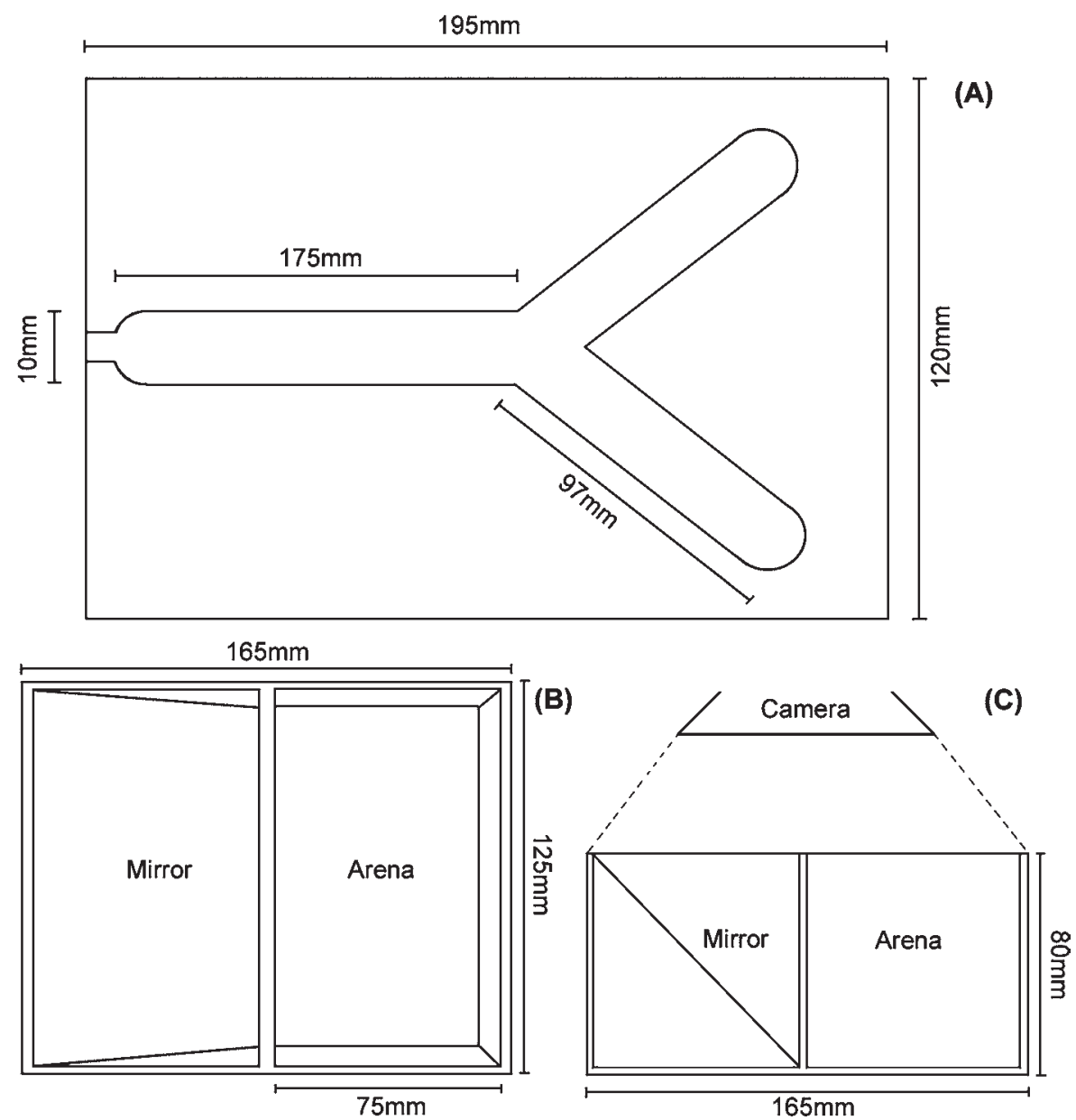

Fig. 1. Schematic diagrams of the behaviour arenas. (A) Choice-chamber plan view. (B) Natural behaviour arena plan view. (C) Natural behaviour arena planar view, showing the position of the camera above the arena.

\section{Experimental setup}

To record the behaviour of the parasites, a Sony Handycam DCR-VX2000E-PAL video camera ( $\mathrm{f}=6-72 \mathrm{~mm}, 58 \mathrm{~mm}+2$ diopter close-up lens) was mounted on a stand with the camera lens $40 \mathrm{~cm}$ above the viewing chamber. The camera was connected to a PC via an S-video cable and digital videos were captured using Adobe Premier software version 7.0 Columbo (Adobe Systems Inc.) at a resolution of $352 \times 288$ pixels and capture rate of 1 frame $\mathrm{s}^{-1}$ for the choice chamber experiment, and a resolution of $720 \times 576$ pixels and a capture rate of 5 frames $\mathrm{s}^{-1}$ for the natural behaviour experiment. Video files were stored on a PC hard drive in *avi format for subsequent analysis.

Four $12 \mathrm{~W}$ halogen lights were mounted in a frame surrounding the experimental chamber and a light diffuser, constructed from a cone of thick, white cotton material and fixed around the chamber and camera, ensured that there were no bright spots, eliminating potential directional cues. A rheostat was wired in series to allow the light intensity to be adjusted to a suitably low level. A light meter (Sekonic L398 Studio Deluxe) was used to check that the light levels inside the diffuser were consistent
(1000 lux). Experiments were conducted in a darkened room during hours of darkness to ensure that there were no extraneous sources of light.

\section{Choice-chamber experiments}

For the choice-chamber experiments, a chamber was constructed from $11 \mathrm{~mm}$ thick white acrylic. An $8 \mathrm{~mm}$ deep, concave, $\mathrm{Y}$-shaped channel was cut into the acrylic with a drainage channel at the base of the $\mathrm{Y}$-shape to allow water to drain from the chamber (Fig. 1A). A $50 \mu \mathrm{m}$ nylon mesh across the drain prevented the escape of parasites. A Watson-Marlow 16-channel peristaltic pump (Watson-Marlow Ltd) coupled with Watson-Marlow Marprene manifold tubing $(1.85 \mathrm{~mm}$ internal diameter) was used to ensure an even flow of water into each arm of the choice chamber. As each channel had a flow rate of $3.33 \mathrm{~mL} \mathrm{~min}^{-1}, 3$ channels were used for each arm of the choice chamber, giving a flow rate of $10 \mathrm{~mL} \mathrm{~min}^{-1}$ for each arm.

For each different chemical cue, 2 beakers of seawater, one containing the cue and the other containing clean seawater, were maintained at $10{ }^{\circ} \mathrm{C} \pm 0 \cdot 5$. Water containing the chemical cue was introduced 
into one arm of the choice chamber and clean seawater was introduced into the other via the peristaltic pump. When switching cues the chamber and pump tubes were cleaned thoroughly by pumping $500 \mathrm{ml}$ of dilute decon (1 g Dri-decon (Decon Laboratories Ltd) in $500 \mathrm{~mL}$ of water) through the system followed by $1 \mathrm{~L}$ of clean seawater. The subsequent chemical cue was pumped through the system until the choice chamber was full and the drain overflowing before starting the next set of experiments.

For each experiment, a single adult female $L$. branchialis was introduced into the chamber close to the drain, with the pump running. The parasite was allowed to acclimatize for $1 \mathrm{~min}$, and once a positive orientation to the water flow was seen, the movements of the parasite were recorded using the video camera for $5 \mathrm{~min}$. Thirty replicate individuals were recorded for each chemical cue from each fish species and the seawater control, giving a total of 510 replicates i.e. $((30 \times 4) \times 4+30)$. As the capture rate was 1 frame $\mathrm{s}^{-1}, 300$ frames were recorded for each replicate. Switching of the cue arm (either left or right) and orientation of the chamber between replicates ensured that other accidental directional cues, such as light, vibration or magnetic fields, would not affect the outcome of the experiments.

\section{Natural behaviour experiments}

The natural behaviour arena was constructed from $0.5 \mathrm{~cm}$ thick clear acrylic and consisted of 2 equally sized chambers separated by a piece of acrylic (Fig. 1B). In the left chamber, a mirror was set at an angle of $45^{\circ}$, allowing parasite movements in the $x y$ plane and $y z$ plane to be recorded using a single camera positioned above the arena (Chrásková et al. 1999) (Fig. 1C). Both chambers of the arena were filled with water to prevent diffraction of the image passing from the arena to the mirror. The outside of the arena was spray-painted white to provide parasite contrast against the background.

For each experiment, an adult female L. branchialis was introduced into the arena containing clean seawater at $10^{\circ} \mathrm{C} \pm 0 \cdot 5$. After an acclimatization period of $3 \mathrm{~min}$, the movements of the parasite were recorded for $3 \mathrm{~min}$. The water was then siphoned from the arena leaving the parasite in approximately $1 \mathrm{~cm}$ depth of water before the arena was carefully topped up with water containing the chemical cue. After another acclimatization period of $3 \mathrm{~min}$, the parasite was recorded again for a further $3 \mathrm{~min}$. After each replicate the chamber was rinsed with Decon solution (1 g Dri-decon in $500 \mathrm{~mL}$ water) and then flushed with clean seawater. Upon analysis of the results from the choice-chamber experiment (see Results section), the decision was made to test only fish-conditioned water from each species of fish. Twenty replicate individuals were recorded for each type of conditioned water and control water, giving a total of 200 replicates. With a capture rate of 5 frames $s^{-1}, 1800$ frames were captured for each replicate.

\section{Data extraction and analysis}

Individual frames were extracted from the video files using Irfanview software (version 3.98, Irfan Skiljan) and saved as a set of bitmap (*.bmp) images. Using a macro in KSRun Macro Execution Environment Rel. 3 (Carl Zeiss, Inc.), the image sets were batch processed using a median filter, shade correction and segmentation analysis. Bespoke tracking software (Paratrack, Brooker, University of Stirling) was used to analyse each image set and extract parasite coordinates for each image, producing a text file of coordinates describing the trajectory for each replicate and a bitmap image of the parasite trajectory. A calibration factor was automatically calculated for each replicate and appended to each text file to allow coordinates to be converted to real distances for analysis. For the choice-chamber experiment, parasite movements were recorded in $2 \mathrm{D}$, whereas in the natural behaviour experiment parasite movements were recorded in $3 \mathrm{D}$ with a logarithmic regression correction factor being applied to the coordinates from each plane to correct for perspective viewing effects.

For the choice-chamber experiment, 3 zones were defined within the Y-chamber: control zone (arm with clean seawater), cue zone (arm with seawater containing fish-derived chemicals) and mixed zone (central channel where mixing of the arms occurred). For each replicate, the time spent in each zone was calculated using Paratrack. In order to calculate behaviour parameters, the 2D distances between each subsequent pair of trajectory coordinates $d$ were calculated as:

$d=\sqrt{\left(x_{t}-x_{t+1}\right)^{2}+\left(y_{t}-y_{t+1}\right)^{2}}$,

where $\left(x_{t}, y_{t}\right)$ and $\left(x_{t+1}, y_{t+1}\right)$ are the parasite coordinates at time $t$ and $t+1$, respectively. Total distance travelled $D$ was calculated as:

$D=\sum_{t=1}^{n} d$

where $n$ is the total number of time steps (i.e. 300). Mean velocity $\mu_{v}$ was calculated as:

$\mu_{v}=\frac{\sum_{t=1}^{n} \frac{d}{t_{r}}}{t_{r} n}$,

where $t_{r}$ is the temporal resolution of the camera (i.e. $1 \mathrm{~s})$. Mean turn rate $\mu_{\theta}$ was calculated as:

$\mu_{\theta}=\frac{\sum_{t=2}^{n} \arccos \frac{d_{1}+d_{2}-d_{3}}{2 d_{1} d_{2}}}{t_{r} n}$, 
where $d_{1}, d_{2}, d_{3}$ are the distances between parasite coordinates at time $t$ and $t+1, t+1$ and $t+2$, and $t$ and $t+2$, respectively. As the choice-chamber data were not normally distributed (Anderson-Darling test), comparisons between each cue source and the control were made using the Wilcoxon Mann-Whitney test (WMW test). Statistical analyses were carried out using Statistica software (Version 7, Statsoft Inc., 2004).

For the natural behaviour experiment, the $3 \mathrm{D}$ trajectory of each replicate was analysed in Paratrack. The distances $d$ between each subsequent pair of trajectory coordinates were calculated as:

$d=\sqrt{\left(x_{t}-x_{t+1}\right)^{2}+\left(y_{t}-y_{t+1}\right)^{2}+\left(z_{t}-z_{t+1}\right)^{2}}$,

where $\left(x_{t}, y_{t}, z_{t}\right)$ and $\left(x_{t+1}, y_{t+1}, z_{t+1}\right)$ are the parasite coordinates at time $t$ and $t+1$, respectively. Total distance, mean velocity, and mean turn rate were calculated in the same way as for the choice-chamber experiment, with the temporal resolution $t_{r}$ being $0 \cdot 2 \mathrm{~s}$ and the number of time steps $n=900$.

In addition, instantaneous velocities $v_{i}$ for each time step were calculated as:

$v_{i}=\frac{d}{t_{r}}$

Instantaneous velocities were categorized into 5 behaviour states (Schmitt et al. 2006) as follows: 'static' where the velocity was $<3 \mathrm{~mm} \mathrm{~s}^{-1}$ and the parasite remained on the bottom (velocities $>0 \mathrm{~mm}$ $\mathrm{s}^{-1}$ may be observed when the parasite is static due to turning on its axis), 'crawl' where the velocity was $>3 \mathrm{~mm} \mathrm{~s}^{-1}$, but the parasite remained on the bottom (velocities $>3 \mathrm{~mm} \mathrm{~s}^{-1}$ were attributed to linear movement and not static turning), 'cruise' where the velocity was $<20 \mathrm{~mm} \mathrm{~s}^{-1}$ and the parasite was in the water column (normal swimming speeds were observed between 8 and $20 \mathrm{~mm} \mathrm{~s}^{-1}$ ), 'fast swimming' where the velocity was $>20 \mathrm{~mm} \mathrm{~s}^{-1}$ (short bursts of speed were characterized by velocities $>20 \mathrm{~mm} \mathrm{~s}^{-1}$ ), and 'sinking' where the velocity was $<8 \mathrm{~mm} \mathrm{~s}^{-1}$ and the parasite moved in a downward direction (velocities $<8 \mathrm{~mm} \mathrm{~s}^{-1}$ were observed as the sedimentation rate of the parasite).

Instantaneous turn angles $\theta_{i}$ were calculated as:

$\theta_{i}=\arccos \frac{d_{1}+d_{2}-d_{3}}{2 d_{1} d_{2}}$

Fractal dimensions were calculated using the 'box counting' method (Seuront et al. 2004; Uttieri et al. 2007). This method finds the number of boxes of length $\lambda$ required to cover the track by superimposing a regular grid of boxes of length $\lambda$ onto the image and counting the number of occupied boxes. The procedure is then repeated using different values for $\lambda$ up to the size of the image. The number of occupied boxes increases with decreasing box size according to the following power law relationship (Loehle, 1990): $N(\lambda)=k \lambda^{-F}$

where $N(\lambda)$ is the number of boxes occupied by the path, $k$ is a constant, and $F$ is the fractal dimension, which can be estimated from the slope of the linear trend of the log-log plot of $N(\lambda)$ vs $\lambda$ (Sreenivasan et al. 1989; Wijesekera, 1996). $F$ gives an estimate of the sinuosity or complexity of the trajectory, with a higher fractal dimension indicating a more complex track. In theory, extreme cases are defined by linear and Brownian movements, giving fractal dimensions of 1 and 2 respectively, and all other examples should fall between these two extremes. In Paratrack, $N(\lambda)$ was calculated for $\lambda$ values in a $2^{\mathrm{n}}$ series (Sandau and Kurz, 1996), ranging from the length of the parasite (i.e. pre-metamorphosed adult female, $1.6 \mathrm{~mm}$ ) to the $2 \mathrm{n}$ value approximating the arena width (i.e. $75 \mathrm{~mm}$ ). This range was selected to ensure that an appropriate range of scales was covered to reliably estimate $F$ ('Turchin, 1996; Halley et al. 2004), as $\lambda$ values smaller than the size of the parasite may have resulted in errors due to the parasite turning on its axis while stationary.

As the natural behaviour data were not normally distributed (Anderson-Darling test), each pair of datasets, before and after the chemical cue was added, were compared using the Wilcoxon matched pairs test (T-test). Differences in behaviour state frequencies, before and after the cue was added, were compared using Pearson's $\chi^{2}$ test. Statistical analyses were carried out using Statistica software (Version 7, Statsoft Inc., 2004). In addition, power-law regressions were fitted to the $\log -\log$ plots of behaviour state duration $v s$ frequency and their regression coefficients were calculated using Microsoft Excel 2003 SP3.

\section{RESULTS}

\section{Choice-chamber experiments}

In the seawater control, L. branchialis spent over half of the experimental time $(51 \cdot 8 \pm 39 \cdot 5 \%)$ in the mixed zone of the choice chamber (Fig. 2). The other portion of the time was divided approximately equally between the cue zone $(23 \cdot 59 \pm 33 \cdot 07 \%)$ and the control zone $(24 \cdot 75 \pm 34 \cdot 89 \%)$. Although there were variations in behaviour of $L$. branchialis when exposed to the various chemical cues, many of these were not significantly different due to the wide variation between replicates.

The strongest response was seen from parasites exposed to flounder feces, although their behaviour suggests repulsion to the cue. Parasites exposed to flounder feces spent $99 \cdot 48 \pm 2 \cdot 27 \%$ of their time in the mixed zone, which was significantly different from the control parasites $(P=<0 \cdot 001)$ (Fig. 2). Parasites exposed to flounder feces also spent significantly less 


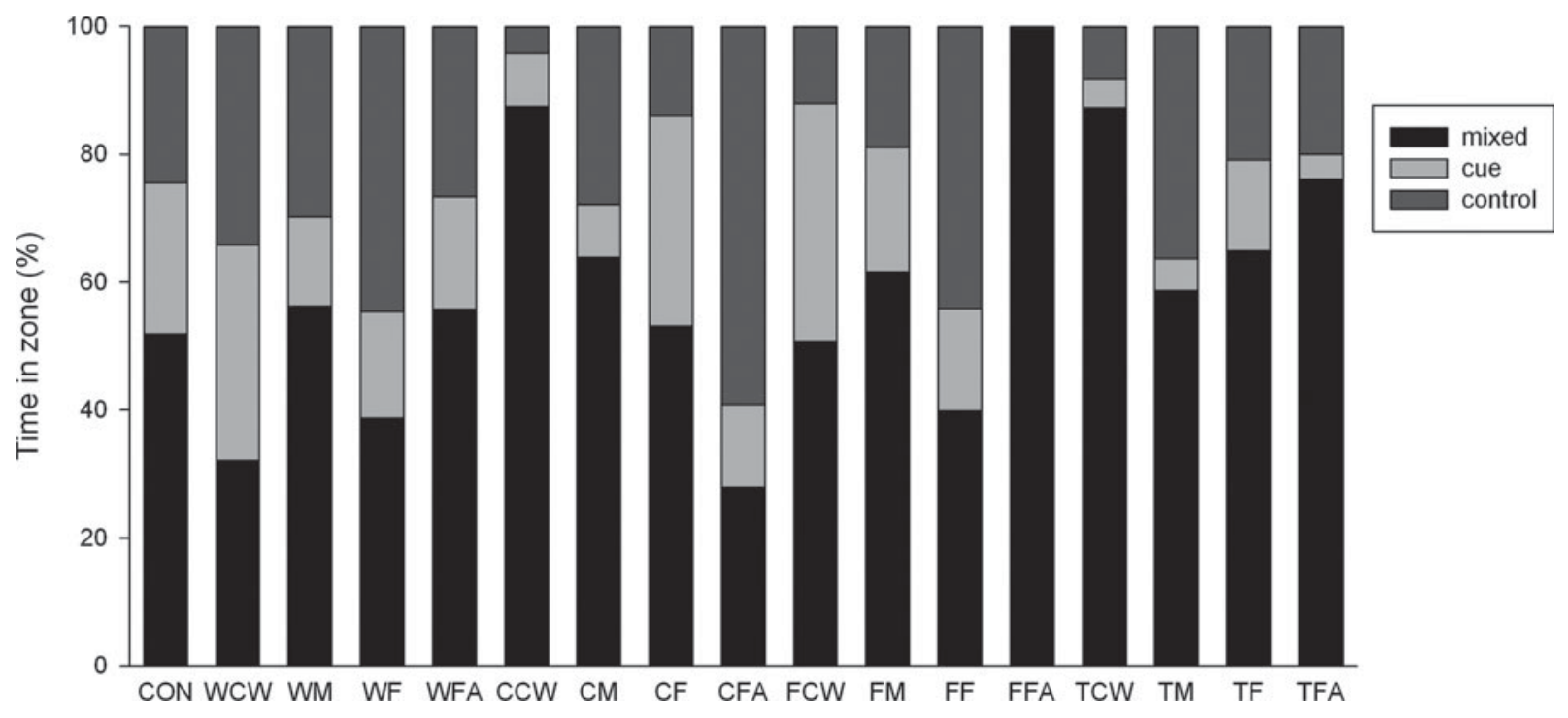

Fig. 2. Time spent in each zone for Lernaeocera branchialis pre-metamorphosed adult females observed in a $\mathrm{Y}$-shaped choice chamber $(n=30)$. CCW, cod-conditioned water; CF, cod flesh; CFA, cod feces; CM, cod mucus; CON, seawater control; FCW, flounder-conditioned water; FF, flounder flesh; FFA, flounder feces; FM, flounder mucus; TCW, troutconditioned water; TF, trout flesh; TFA, trout feces; TM, trout mucus; WCW, whiting-conditioned water; WF,

whiting flesh; WFA, whiting feces; WM, whiting mucus.

time in the cue zone $(P=0.0014)$ and control zone $(P=0 \cdot 0341)$. In addition, they had a lower velocity $\left(1 \cdot 22 \pm 1 \cdot 248 \mathrm{~mm} \mathrm{~s}^{-1}\right)$, travelled less distance $(36 \cdot 51 \pm 37 \cdot 28 \mathrm{~cm})$ and had a lower turn rate (59.90 $\pm 40 \cdot 16$ degrees $\mathrm{s}^{-1}(P=<0 \cdot 001)$ (Fig. 3). Similarly, the behaviour of parasites exposed to cod feces, trout feces, trout-conditioned water and trout mucus, also suggests repulsion to these cues, albeit less pronounced.

Of the definitive host cues, parasites exposed to whiting-conditioned water and cod flesh spent more time in the mixed zone than control parasites, although none of these differences was significant $(P>0 \cdot 05)$. However, parasites exposed to whitingconditioned water had a higher velocity $\left(5 \cdot 31 \pm 2.31 \mathrm{~mm} \mathrm{~s}^{-1}, P=0.0428\right)$, travelled further $(158.74 \pm 68.98 \mathrm{~cm}, P=0.0428)$ and had a higher turn rate $\left(161.53 \pm 37.52\right.$ degrees $\left.\mathrm{s}^{-1}, P=0.0042\right)$ than control parasites (Fig. 3). This increased activity suggests attraction to whiting-conditioned water.

\section{Natural behaviour experiments}

In the seawater control, the behaviour of $L$. branchialis before and after the water was replaced in the arena was not significantly different $(P>0 \cdot 05$ for all parameters) and consequently the data were grouped together to define normal behaviour. Mean distance travelled was $31 \cdot 1 \pm 23 \cdot 4 \mathrm{~cm}$ in $3 \mathrm{~min}$ with a velocity of $1.74 \pm 1.31 \mathrm{~cm} \mathrm{~s}^{-1}$. A high turn rate of $71 \cdot 62 \pm 46 \cdot 7$ degrees $\mathrm{s}^{-1}$ was observed, resulting in a number of relatively complex path shapes, giving a mean fractal dimension of $1 \cdot 38 \pm 0 \cdot 31$.

Of the four chemical cues tested, the most significant differences between cue presence and absence were observed for whiting-conditioned and for trout-conditioned water. However, due to the high degree of variability within groups, the levels of significance of differences between groups were low. In whiting-conditioned water, velocity increased from $0.64 \pm 0.63 \mathrm{~mm} \mathrm{~s}^{-1}$ before the cue was added to $1.84 \pm 1 \cdot 14 \mathrm{~mm} \mathrm{~s}^{-1}$ after the cue was added $(P=0.0012)$; distance travelled increased from $11 \cdot 38 \pm 11 \cdot 29 \mathrm{~cm}$ to $32 \cdot 87 \pm 20 \cdot 44 \mathrm{~cm}(P=0 \cdot 0012)$; turn rate increased from $27 \cdot 22 \pm 28 \cdot 93$ degrees s $^{-1}$ to $76 \cdot 17 \pm 45 \cdot 48$ degrees $\mathrm{s}^{-1} \quad(P=0 \cdot 0013)$; fractal dimension increased from $1 \cdot 04 \pm 0 \cdot 30$ to $1 \cdot 29 \pm 0 \cdot 44$ $(P=0.0304)$ (Fig. 4). In trout-conditioned water, velocity increased from $1 \cdot 88 \pm 1 \cdot 28 \mathrm{~mm} \mathrm{~s}^{-1}$ before the cue was added, to $3 \cdot 02 \pm 1.49 \mathrm{~mm} \mathrm{~s}^{-1}$ after the cue was added $(P=0.0017)$; distance travelled increased from $33.89 \pm 22.93 \mathrm{~cm}$ to $54.22 \pm 26.68 \mathrm{~cm}$ $(P=0.0017)$; turn rate increased from $66.99 \pm$ $36 \cdot 38$ degrees $\mathrm{s}^{-1}$ to $101 \cdot 39 \pm 31 \cdot 90$ degrees $\mathrm{s}^{-1}$ $(P=0.0017)$; fractal dimension increased from $1 \cdot 37 \pm 0 \cdot 23$ to $1 \cdot 63 \pm 0 \cdot 23(P=0 \cdot 0036)($ Fig. 4$)$. The increase in activity after the cue was added indicates that the parasites may be excited by the addition of whiting- and trout-conditioned water. In flounderconditioned water, velocity decreased from $2 \cdot 51 \pm 1.79 \mathrm{~mm} \mathrm{~s}^{-1}$ before the cue was added to $1.96 \pm 1.10 \mathrm{~mm} \mathrm{~s}^{-1}$ after the cue was added $(P=0.0366)$, and distance travelled decreased from $45.08 \pm 31.96 \mathrm{~cm}$ to $35.08 \pm 19.59 \mathrm{~cm} \quad(P=0.0366)$ (Fig. 4). This decrease in activity suggests that flounder-conditioned water did not elicit an attraction response and may be repulsive to the parasites. In cod-conditioned water track complexity increased after the cue was added, with fractal dimension increasing from $1 \cdot 43 \pm 0 \cdot 22$ before the cue source was 

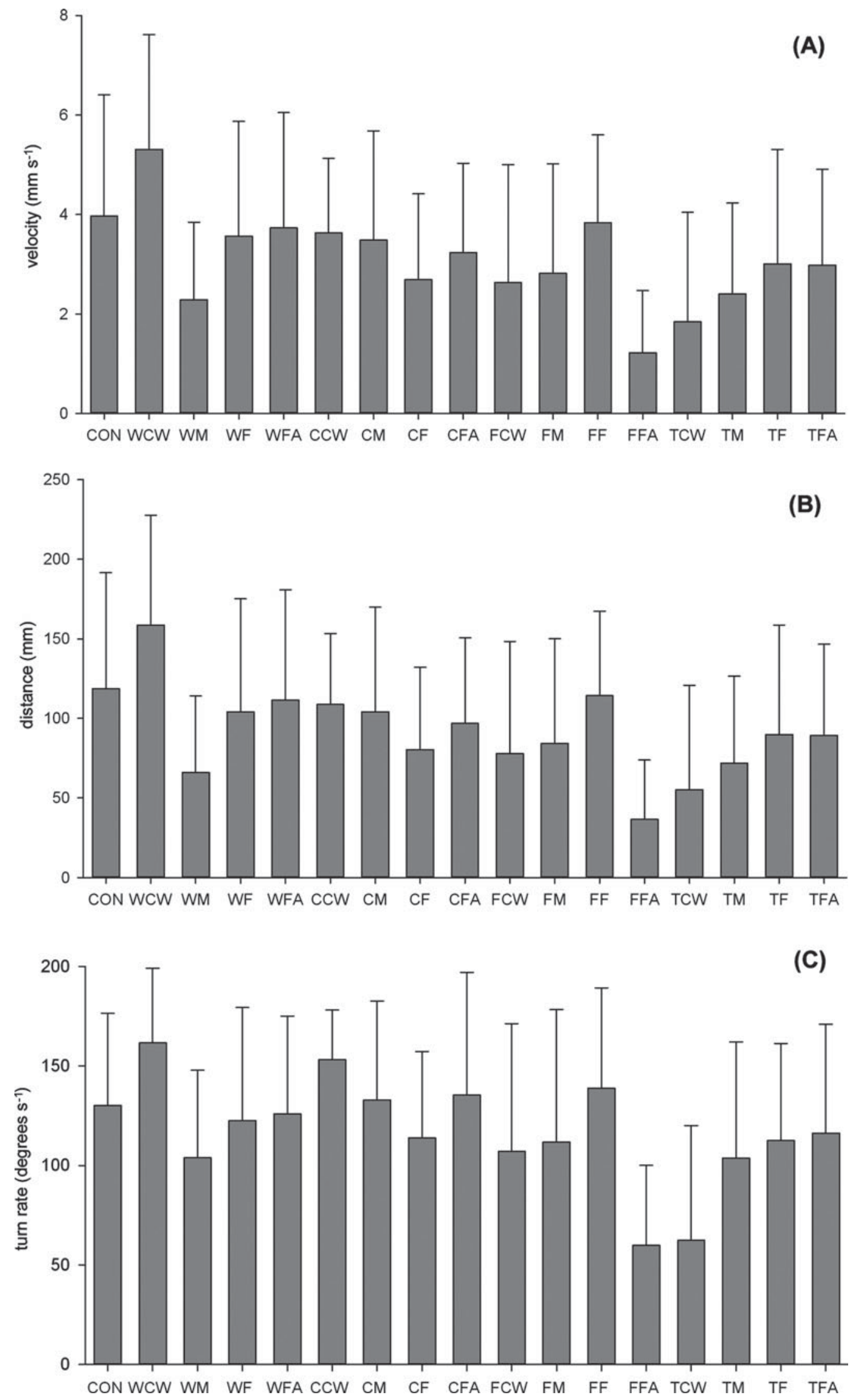

Fig. 3 (A) Mean velocity, (B) mean distance travelled and (C) mean turn rate for Lernaeocera branchialis premetamorphosed adult females observed in a Y-shaped choice chamber $(n=30$, bars $=1$ s.D. $)$. CCW, cod-conditioned water; CF, cod flesh; CFA, cod feces; CM, cod mucus; CON, seawater control; FCW, flounder-conditioned water; FF, flounder flesh; FFA, flounder feces; FM, flounder mucus; TCW, trout-conditioned water; TF, trout flesh; TFA, trout feces; TM, trout mucus; WCW, whiting-conditioned water; WF, whiting flesh; WFA, whiting feces; WM, whiting mucus. 

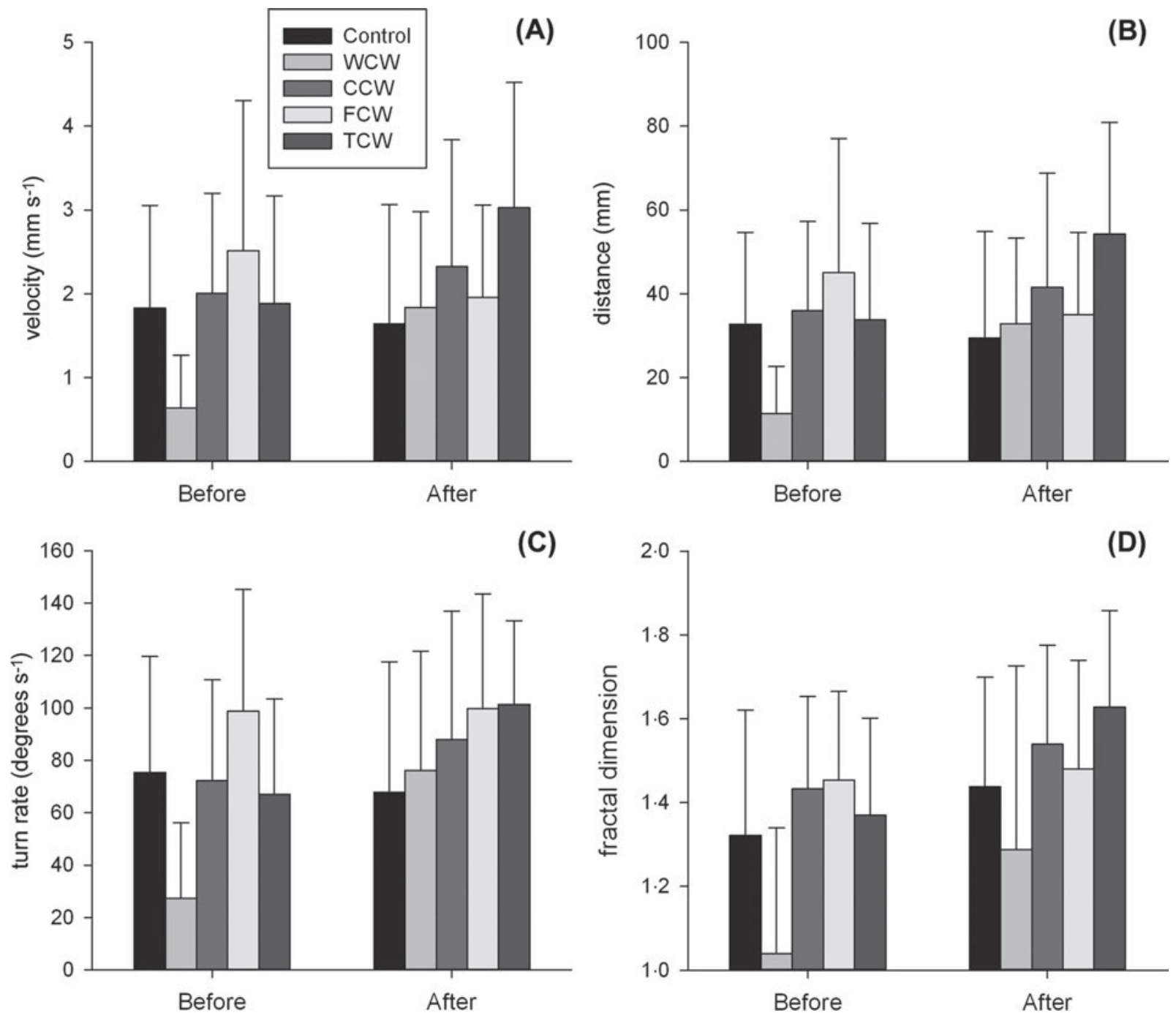

Fig. 4. Behaviour measurements of Lernaeocera branchialis pre-metamorphosed adult females before and after exposure to fish-conditioned water $(n=20$, bars $=1$ s.D.). (A) Mean velocity. (B) Mean distance travelled. (C) Mean turn rate. (D) Fractal dimension. CCW, cod-conditioned water; Control, seawater control; FCW, flounder-conditioned water; TCW, trout-conditioned water; WCW, whiting-conditioned water.

added to $1 \cdot 54 \pm 0 \cdot 24$ after the cue was added $(P=0 \cdot 0152)$. Other behaviour parameters did not change significantly, suggesting that parasites were not excited by the addition of cod-conditioned water (Fig. 4).

Before the cue was added, velocity, distance travelled, turn rate and fractal dimension were significantly lower for the cohort of animals exposed to whiting-conditioned water, than all other cues $(P=<0 \cdot 01)$ (Fig. 4). These differences in behaviour before the addition of cues may be a result of different cohorts of $L$. branchialis having varying levels of fitness and illustrates the dangers of directly comparing behaviour between individuals as opposed to comparing the same individuals before and after adding the chemical cue.

Behaviour state frequencies for the seawater controls were divided approximately equally between static, crawl, cruise and sink states $(0 \cdot 25,0 \cdot 23,0 \cdot 29$ and $0 \cdot 22$, respectively) (Fig. 6A). As the fast swimming state accounted for $<2 \%$ of the total observations for all cues, it was discounted from subsequent probability density functions and statistical analyses.

A broad variation in the probability density functions was observed for the static state, with long durations over $100 \mathrm{~s}$ recorded for all cues and controls (Fig. 5C). For the other behaviour states (crawl, cruise and sink), maximum duration was limited to $<20 \mathrm{~s}$ (Fig. 5D-F). For the crawl and cruise states, considerable variation in duration frequency was observed between cues at higher durations, although for the sink state, variation in frequencies between cues was limited for all durations.

Probability density functions for velocities and turn rates were not significantly different after the addition of conditioned water from any of the fish species tested. The most common velocity for all groups was $4 \mathrm{~mm} \mathrm{~s}^{-1}$, with frequencies of between 

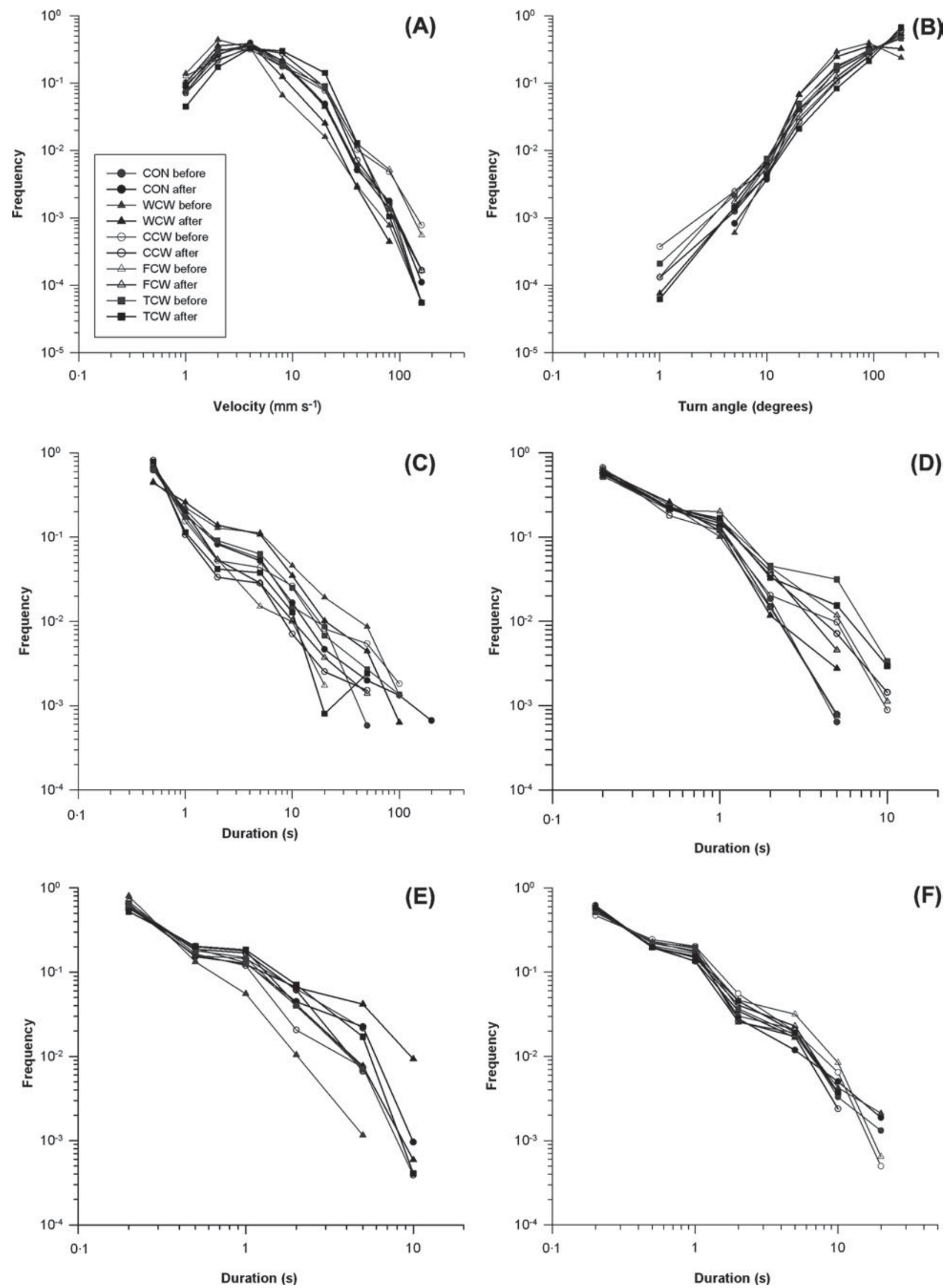

Fig. 5. Probability density functions for Lernaeocera branchialis pre-metamorphosed adult females before and after exposure to fish-conditioned water. (A) Velocities. (B) Turn angles. (C) Static state. (D) Crawling state. (E) Cruising state. (F) Sinking state. CCW, cod-conditioned water; CON, seawater control; FCW, flounder-conditioned water; $\mathrm{TCW}$, trout-conditioned water; $\mathrm{WCW}$, whiting-conditioned water. 

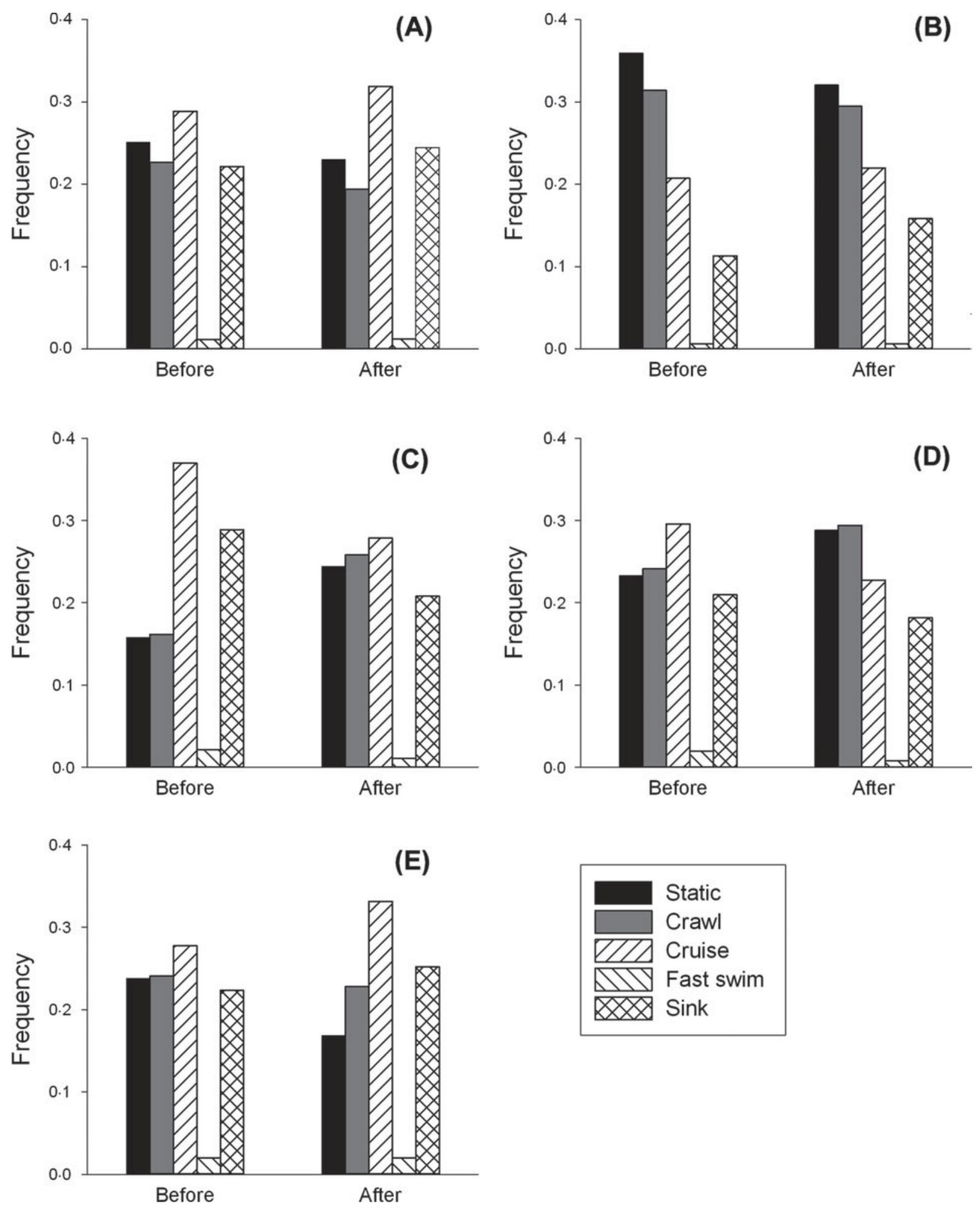

Fig. 6. Behaviour state frequencies of Lernaeocera branchialis pre-metamorphosed females $(n=20)$ before and after exposure to (A) seawater control, (B) whiting-conditioned water, (C) cod-conditioned water, (D) flounder-conditioned water and $(\mathrm{E})$ trout-conditioned water.

0.31 and 0.39 for all cues and controls (Fig. 5A). The frequency of velocities decreased at higher and lower velocities, with velocities over $100 \mathrm{~mm} \mathrm{~s}^{-1}$ having a frequency of $<4 \times 10^{-4}$ for all groups. Frequencies of turn rates increased with increasing turn rate, with frequencies ranging from $6 \times 10^{-5}$ to $4 \times 10^{-4}$ at 1 degree $\mathrm{s}^{-1}$, to 0.23 to 0.67 at 180 degrees $\mathrm{s}^{-1}$
(Fig. 5B). Although the trend was linear for most groups, the control and whiting-conditioned water groups were described by a shallow sigmoid curve.

In the whiting-conditioned water group, behaviour state frequencies showed little variation before and after the cue was added $(0 \cdot 36$ vs $0 \cdot 32,0 \cdot 31$ vs $0 \cdot 3$, $0 \cdot 21$ vs 0.22 and 0.11 vs $0 \cdot 16$ for static, crawl, cruise 
Table 1. Regression coefficients and $\mathrm{R}^{2}$ values for power-law regressions calculated for probability density functions of Lernaeocera branchialis pre-metamorphosed adult females before and after exposure to fish-conditioned water

(CCW, cod-conditioned water; $\mathrm{CON}$, seawater control; FCW, flounder-conditioned water; TCW, trout-conditioned water; WCW, whiting-conditioned water.)

\begin{tabular}{|c|c|c|c|c|c|c|c|c|c|}
\hline & & \multicolumn{2}{|l|}{ Static } & \multicolumn{2}{|l|}{ Crawl } & \multicolumn{2}{|l|}{ Cruise } & \multicolumn{2}{|l|}{ Sink } \\
\hline & & Coeff. & $\mathrm{R}^{2}$ & Coeff. & $\mathrm{R}^{2}$ & Coeff. & $\mathrm{R}^{2}$ & Coeff. & $\mathrm{R}^{2}$ \\
\hline \multirow[t]{2}{*}{$\mathrm{CON}$} & Before & $-1 \cdot 36$ & $0 \cdot 95$ & $-2 \cdot 08$ & $0 \cdot 90$ & -0.98 & $0 \cdot 96$ & $-1 \cdot 33$ & 0.96 \\
\hline & After & $-1 \cdot 14$ & 0.99 & $-2 \cdot 06$ & 0.92 & $-1 \cdot 45$ & $0 \cdot 88$ & $-1 \cdot 27$ & 0.98 \\
\hline \multirow[t]{2}{*}{ WCW } & Before & -0.99 & $0 \cdot 94$ & $-2 \cdot 08$ & 0.94 & $-0 \cdot 20$ & 0.99 & $-1 \cdot 25$ & 0.96 \\
\hline & After & $-1 \cdot 17$ & 0.95 & $-1 \cdot 76$ & 0.95 & -0.94 & 0.95 & $-1 \cdot 14$ & 0.98 \\
\hline \multirow[t]{2}{*}{ CCW } & Before & $-1 \cdot 00$ & 0.96 & $-1 \cdot 60$ & 0.96 & $-1 \cdot 78$ & 0.94 & $-1 \cdot 40$ & 0.91 \\
\hline & After & $-1 \cdot 29$ & 0.95 & $-1 \cdot 54$ & $0 \cdot 96$ & $-1 \cdot 29$ & $0 \cdot 91$ & $-1 \cdot 35$ & 0.96 \\
\hline \multirow[t]{2}{*}{ FCW } & Before & $-1 \cdot 52$ & 0.98 & $-1 \cdot 50$ & 0.92 & $-1 \cdot 34$ & $0 \cdot 96$ & $-1 \cdot 31$ & 0.90 \\
\hline & After & $-1 \cdot 32$ & $0 \cdot 99$ & $-1 \cdot 47$ & 0.94 & $-1 \cdot 68$ & $0 \cdot 92$ & $-1 \cdot 21$ & 0.96 \\
\hline \multirow{2}{*}{ TCW } & Before & $-1 \cdot 13$ & $0 \cdot 98$ & $-1 \cdot 19$ & 0.92 & $-1 \cdot 36$ & $0 \cdot 97$ & $-1 \cdot 25$ & 0.95 \\
\hline & After & $-1 \cdot 31$ & $0 \cdot 87$ & $-1 \cdot 31$ & 0.96 & $-1 \cdot 62$ & $0 \cdot 83$ & $-1 \cdot 23$ & 0.96 \\
\hline
\end{tabular}

and sink, respectively) (Fig. 6B). Probability density functions for the crawl and sink states before and after the cue was added were significantly different ( $P=0.019$ and $P=0.035$, respectively) (Fig. 5D, F). However, the differences in the probability density functions for the cruise state before and after the cue was added were highly significant $(P=<0 \cdot 001)$, with the regression coefficients for the power-law regressions decreasing from $-0 \cdot 20$ to -0.94 (Table 1 ). This was the largest change in the probability density function for any cue and suggests that the addition of whiting-conditioned water excited the parasites, resulting in an increase in the number of long-duration cruise events.

In the cod-conditioned water group, the frequency of the static and crawl states increased and the frequency of the cruise and sink states decreased after the addition of cod-conditioned water $(0 \cdot 16 \mathrm{vs}$ $0 \cdot 24,0 \cdot 16$ vs $0 \cdot 26,0 \cdot 37$ vs $0 \cdot 28$ and 0.29 vs $0 \cdot 21$, for the static, crawl, cruise and sink states, respectively) (Fig. 6C). Significant differences in the probability density functions after the cue was added were seen for all behaviour states $(P=<0 \cdot 001)$ (Fig. 5). Changes in the regression coefficients before and after the cue source was added, however, were low $(-1.00$ vs $-1.29,-1.60$ vs $-1.54,-1.78$ vs -1.29 and -1.40 vs -1.35 for static, crawl, cruise and sink, respectively) (Table 1 ). As the addition of codconditioned water resulted in a decrease in longduration events for the crawl, cruise and sink states, and an increase in long-duration events for the static state, this suggests that the parasites were not excited by the addition of cod-conditioned water.

In the flounder-conditioned water group, a similar response to cod-conditioned water was seen, with the frequency of the static and crawl states increasing and the frequency of the cruise and sink states decreasing after the addition of flounder-conditioned water $(0 \cdot 23$ vs $0 \cdot 29,0 \cdot 24$ vs $0 \cdot 29,0 \cdot 30$ vs $0 \cdot 23$ and $0 \cdot 21$ vs $0 \cdot 18$ for static, crawl, cruise and sink states, respectively) (Fig. 6D). While the regression coefficients for the static, crawl and sink states indicated a decrease in the frequency of long duration events after the addition of the cue $(-1.52$ vs $-1.32,-1.50$ vs -1.47 and $-1 \cdot 31$ vs $-1 \cdot 21$, respectively), an increase in the frequency of long duration events was seen for the cruise state $(-1 \cdot 34$ vs $-1 \cdot 68, P=0 \cdot 011)$ ('Table 1$)$.

In the trout-conditioned water group, the opposite was observed with respect to cod- and flounderconditioned water, with the frequency of the static and crawl states decreasing and the frequency of the cruise and sink states increasing after the addition of the cue $(0 \cdot 24$ vs $0 \cdot 17,0 \cdot 24$ vs $0 \cdot 23,0 \cdot 28$ vs $0 \cdot 33$ and $0 \cdot 22$ vs $0 \cdot 25$ for static, crawl, cruise and sink states, respectively) (Fig. 6E). Significant differences in the probability density functions were observed for the static and cruise states $(P=<0 \cdot 001)$ and the crawl state $(P=0.033)$ (Fig. $5 \mathrm{C}-\mathrm{E})$, with the regression coefficients decreasing after the addition of the cue $(-1 \cdot 13$ vs $-1 \cdot 31,-1 \cdot 19$ vs $-1 \cdot 31$ and $-1 \cdot 36$ vs $-1 \cdot 62$ for the static, crawl and cruise states, respectively) (Table 1), indicating an increase in the frequency of long-duration events. A decrease in the frequency of long-duration events was seen for the sink state after the addition of trout-conditioned water, with the regression coefficient increasing from $-1 \cdot 25$ to $-1 \cdot 23$ $(P=0.032)$.

\section{DISCUSSION}

\section{Behavioural responses}

The host-finding behaviour of $L$. branchialis might be expected to be largely dependent upon the habits of its hosts, allowing the parasite to increase the likelihood of host encounter. The normal behaviour of L. branchialis, as observed in the controls, is indicative of a parasite searching for a demersal host 
fish. The majority of their time was spent static or crawling on the bottom, with long periods in these states. In comparison, cruise events were shorter and less frequent. This behaviour suggests that the parasites are periodically swimming up in the water column, in order to detect a host, with longer periods on the bottom to conserve energy reserves. Whilst moving, the parasites exhibited a high degree of turning, allowing them to cover an area thoroughly and improve their chance of detecting a host. This high track sinuosity during searching behaviour has also been demonstrated for other copepod species such as Temora longicornis, Müller, 1785 where males swim along more sinuous routes than females to increase the chance of encounter with a mate (Doall et al. 1998).

In comparison with the behaviour of L. branchialis, which predominantly remain on the bottom, L. salmonis parasitizes migratory salmonids, which utilize different depths in the water column. Consequently, the behaviour of $L$. salmonis is adapted to increase the chance of encounter with their hosts. Copepodids of L. salmonis undergo a diel vertical migration, moving to the surface during the day and deeper water at night (Heuch et al. 1995). As Atlantic salmon (Salmo salar) frequent surface waters at night and occupy deeper water during the day (Holm et al. 1982; Westerberg, 1982; Doving et al. 1985; Dutil and Coutu, 1988), they cross over as L. salmonis copepodids migrate upwards and salmon move downwards at dawn, allowing infection to take place. Since the flatfish intermediate hosts of L. branchialis are benthic and the definitive hosts are commonly demersal, they have no need to migrate upwards in the water column and this is reflected in their behaviour patterns. Although the arena used in this experiment was only $8 \mathrm{~cm}$ deep, the parasites spent the majority of their time in the bottom quarter of the arena. Unlike Atlantic salmon, which are only exposed to L. salmonis for brief periods during their migrations in the water column, the hosts of L. branchialis are continually exposed to the parasite, which may contribute to the high prevalence of infection seen in some areas.

With the addition of some fish-derived odours into the arena, some of the behavioural responses of L. branchialis were exaggerated: velocity increased, they travelled further and turn rate increased, producing more complex tracks. This increased turn rate allows them to explore an area more extensively where a host chemical signal has been detected, whereas the increased velocity and movement increases the chances of encountering the host. This behaviour was induced by the addition of whiting-conditioned water, as may be expected, being derived from a suitable host, but also by trout-conditioned water. However, the response to trout-conditioned water was not as strong as the response to whiting-conditioned water. In addition, a significant increase was seen in the frequency of long duration cruise events after the addition of whiting-conditioned water, which suggests a response to an attractive host kairomone. A similar response to semiochemicals has been observed in other copepods and may be likened to the frequent turning of insects moving upwind in an odour plume (Murlis et al. 1992). For example, L. salmonis copepodids increase their speed and change direction frequently in the presence of kairomones in the water derived from Atlantic salmon (Devine et al. 2000).

The change in behaviour of $L$. branchialis in the presence of host-derived kairomones, as demonstrated in this study, is not without cost or risk. The increase in velocity and distance travelled increases the consumption of energy reserves, as well as increasing the chance of encounter with a predator. Moreover, the high turn rates may make the parasites more attractive to predators such as fish (Tiselius and Jonsson, 1990; Doall et al. 1998).

Contrary to their behaviour when exposed to whiting-conditioned water, the responses of $L$. branchialis to flounder-derived substances were reversed; average velocity decreased, they travelled less distance and turn rate decreased; the frequency of the static and crawl states increased and the frequency of the cruise and sink states decreased. In the choice chamber experiment, parasites showed a strong aversion to flounder feces by avoiding the chamber arm containing the cue. This behaviour suggests a repulsion response to flounder-derived odours, which is unsurprising, considering that the parasites have recently left their flounder intermediate hosts and are searching for gadoid hosts.

\section{Implications for host preference}

Whereas a strong attraction to whiting-derived odours was not unexpected, it was surprising that cod-derived odours did not elicit a similar response. Currently L. branchialis is viewed as a genetically homogeneous population infecting a range of gadoids. Therefore, as both cod and whiting are recorded as definitive hosts (Brooker et al. 2007), a similar response may be expected to odours derived from both species. The different behavioural response to whiting-conditioned water and cod-conditioned water in this study, however, suggests that cod and whiting are not treated in the same way by the parasite. Interestingly, at the field site where the parasites were collected, almost all whiting were infected with $L$. branchialis, whereas virtually all cod were uninfected. This evidence raises 2 alternative hypotheses: either that there are genetically determined subspecies or host preferences in L. branchialis, or that there is some form of environmental pre-conditioning, either maternally derived or at the egg/nauplius stages, that allows the 
parasite to preferentially recognize the host species from which it originated.

Genetically determined subspecies have already been demonstrated in several other parasitic copepods. In Caligus elongatus von Nordmann, 1832 analysis of the mtDNA gene CO1 has revealed 2 types of genetic lineages (Øines and Heuch, 2005). Analysis of the genetic structure of Lepeophtheirus europaensis Zeddam, 1988 has shown polymorphism between those parasitic on brill (Scophthalmus rhombus) and those on flounder (De Meeus et al. 1992) and is attributed to salinity imparting a strong environmental selective pressure on $L$. europaensis parasitic on flounder in coastal lagoons. A similar differential preference for different fish hosts was also demonstrated in Lepeophtheirus pectoralis (Boxshall, 1976). Given that the process of subspeciation has been demonstrated in other parasitic copepods and that $L$. branchialis show a different behavioural response to whiting- and cod-derived substances, it is possible that this process is also occurring in L. branchialis, although the selective pressures driving such subspeciation are uncertain at this stage.

\section{Implications for host location}

Host location mechanisms can be divided into 3 categories: those which bring the parasite into the host's habitat; those which assist the parasite to respond to and come into contact with the host; and those which allow the parasite to recognize a suitable host (Heuch et al. 2007). Mechanisms used for the first phase of host location (inhabiting the same waters as the host) have not been investigated in L. branchialis, although Sproston (1942) suggested that $L$. branchialis is not a strong swimmer. The results of the natural behaviour experiment, however, suggest that L. branchialis has considerable swimming capabilities and may be able to cover moderate distances to locate a host. The mean distance covered by parasites exposed to whiting-conditioned water in 3 min was $32.87 \pm 20.44 \mathrm{~cm}$, which equates to $6.57 \mathrm{~m}$ $\mathrm{h}^{-1}$ and gives some idea of the mobility of the parasite and its host-seeking ability. These figures suggest that L. branchialis can cover a moderate distance to locate a host. In comparison, distances covered by L. salmonis when excited by the presence of salmonconditioned water were $45 \cdot 2 \pm 8 \cdot 3 \mathrm{~cm}$ for a $3-\mathrm{min}$ period, giving a velocity of $9 \cdot 04 \mathrm{~m} \mathrm{~h}^{-1}$ (Devine et al. 2000). Whether physical phenomena, such as tidal currents, haloclines and thermoclines, are used during this phase, or if location of the host's habitat is purely by chance is not known. Mechanisms involved in this phase of host location may include aggregating in areas where potential hosts are likely to be found or chemo-reception of fish-derived odours. For example, L. salmonis aggregate in steep salinity gradients which may be frequented by feeding salmon (Heuch, 1995). The ability of L. branchialis to utilize kairomones at this scale is dependent on odour landscapes, which are shaped by physical factors such as stirring and mixing in the water body (Moore and Crimaldi, 2004).

As the responses of $L$. branchialis to host-derived kairomones were not decisive in both the choice chamber and natural behaviour experiments, it is likely that $L$. branchialis employs a range of mechanisms in the second phase of host location (response to a potential host). In L. branchialis these other cues have yet to be determined, but in L. salmonis physical cues have been shown to play a role in host location. Copepodids of $L$. salmonis have been shown to react positively to directional light (Lewis, 1963; Bron et al. 1993; MacKinnon, 1993; Pike et al. 1993) and are sensitive to vibrations and flows, resulting in faster swimming and turning behaviour to attack fish (Bron et al. 1993; Heuch and Karlsen, 1997; Heuch et al. 2007). Heuch et al. (2007) showed that copepodids of $L$. salmonis respond positively to hydromechanical signals from fish in the absence of fish-derived odours, and suggested that physical cues are utilized for host detection and kairomones are used for host recognition, once the parasite has attached to the host. Studies have shown that copepodids of L. salmonis will infect species other than salmonids, but will abandon these within hours of contact (Olsen, 2001). However, other workers have demonstrated that $L$. salmonis copepodids show an attraction response to host-derived chemical cues in choice chamber experiments (Devine et al. 2000; Bailey et al. 2006), showing that kairomones have a role to play in locating a host. Similarly, it has been suggested that $L$. pectoralis uses physical stimuli, such as currents and vibrations, to locate the host and chemical stimuli to recognize a suitable host when in close proximity (Boxshall, 1976).

The results of this study suggest that in L. branchialis, kairomones are used to locate a host, as the addition of specific kairomone sources in the water elicits a response suggestive of host-seeking behaviour. The variation in behaviour and vague responses of some parasites, however, suggests that kairomones alone are not sufficient to locate and detect a host and it is likely that physical cues also have a role to play in host location. Indeed, in the choice chamber experiment, parasites were sometimes observed swimming in the inflow current of the chamber, indicating that $L$. branchialis may orientate themselves towards a current, which could have a role to play in host location. Once a host has been located, kairomones must also be utilized to ensure that the species is suitable for infection. Chemical host identification on contact with the host has been demonstrated in L. pectoralis (Boxshall, 1976), Lernaeenicus sprattae Sowerby, 1806 (Anstensrud and Schram, 1988) and L. salmonis (Bron et al. 1991, 1993). It seems likely, therefore, that L. branchialis 
may utilize kairomones to both locate a host and ensure that is it suitable for infection.

Although this study has established that conditioned water from some host species induces a host-seeking response in $L$. branchialis, the specific kairomone compounds in fish-conditioned water that attract $L$. branchialis to its host were not identified. In other species, however, a great diversity of different attractant compounds has been found. Structurefunction studies have shown that neutral amino-acid compounds with a basic carboxyl terminal are commonly used in marine organisms for modifying physiological and behavioural responses (Rittschof and Cohen, 2004). Gas chromatography and mass spectrometry have been used successfully to extract specific compounds from salmon-conditioned water and number of small molecules have been identified which may play a role in host location in L. salmonis (Ingvarsdottir et al. 2002). Both isophorone and 1-octen-3-ol (low molecular weight components of fish odour) cause activation responses from the lice and induce electrophysiological responses from the antennae. Following on from this study, similar extraction techniques with whiting-conditioned water may be used to determine the specific compounds that elicit an attraction response in L. branchialis.

\section{Conclusions}

While the results of this study are interesting, the application of this information may prove to be of greater significance. L. branchialis is regarded as a pathogen that could be potentially devastating to gadoid aquaculture in North Atlantic countries (Khan et al. 1990; Bricknell et al. 2006) and given its widespread distribution in the North Atlantic and pathogenicity to its host (Brooker et al. 2007), it must have significant effects on juvenile recruitment to wild gadoid fisheries. By modelling the behaviour of $L$. branchialis and coupling it with biophysical models of host distributions and current regimes, it may be possible to predict the effects of $L$. branchialis on wild gadoid populations or farmed gadoids, by modelling their distribution from intermediate host habitats. This type of complex model has recently been achieved by Staaterman et al. (2012), who predicted the fate of virtual reef fish larvae and their recruitment to coral reefs. Furthermore, identification of the specific kairomone compounds utilized by $L$. branchialis may be used to develop targeted control mechanisms in gadoid aquaculture, similar to those suggested by Ingvarsdottir et al. (2002) for capture of sea lice using slow-release odour traps. These examples illustrate how this type of detailed behavioural information might be applied to ameliorate the effects of this commercially significant pathogen on wild and cultured gadoid populations.

\section{ACKNOWLEDGEMENTS}

This project was funded by a NERC studentship awarded to A.J.B.

\section{REFERENCES}

Anstensrud, M. (1990). Effects of mating on female behaviour and allometric growth in the two parasitic copepods Lernaeocera branchialis (L., 1767) (Pennellidae) and Lepeophtheirus pectoralis (Muller, 1776) (Caligidae). Crustaceana 59, 245-258.

Anstensrud, M. and Schram, T. A. (1988). Host and site selection by larval stages and adults of the parasitic copepod Lernaeenicus sprattae (Sowerby) (Copepoda, Pennellidae) in the Oslofjord. Hydrobiologia 167-168, 587-595.

Bailey, R. J. E., Birkett, M. A. and Ingvarsdottir, A. (2006). The role of semiochemicals in host location and non-host avoidance by salmon louse (Lepeophtheirus salmonis) copepodids. Canadian Yournal of Fisheries and Aquatic Science 63, 448-456.

Begg, G. S. and Bruno, D. W. (1999). The common dab as definitive host for the pennellid copepods Lernaeocera branchialis and Haemobaphes cyclopterina. Fournal of Fish Biology 55, 655-657.

Boxshall, G. A. (1976). The host specificity of Lepeophtheirus pectoralis (Müller, 1776) (Copepoda: Caligidae). Fournal of Fish Biology 8, 255-264. Bricknell, I. R., Bron, J. E. and Bowden, T. J. (2006). Diseases of gadoid fish in cultivation: a review. ICES fournal of Marine Science 63, 253-266. Bron, J. E., Sommerville, C., Jones, M. and Rae, G. H. (1991). The settlement and attachment of early stages of the salmon louse, Lepeoptheirus salmonis (Copepoda: Caligidae) on the salmon host, Salmo salar. Fournal of Zoology 224, 201-212.

Bron, J. E., Sommerville, C. and Rae, G.H. (1993). Aspects of the behaviour of the salmon louse Lepeophtheirus salmonis (Krøyer, 1837). In Pathogens of Wild and Farmed Fish: Sea Lice (ed. Boxshall, G. A. and Defaye, D.), pp. 125-142. Ellis Horwood, Chichester, UK.

Brooker, A. J., Shinn, A. P. and Bron, J. E. (2007). Review of the biology of the parasitic copepod Lernaeocera branchialis (L. 1767) (Copepoda: Pennellidae). Advances in Parasitology 65, 297-341.

Capart, A. (1947). Le Lernaeocera branchialis (L.), copepode parasite des gadides. Fournal du Conseil International pour l'Exploration de la Mer 15, 69-76.

Capart, A. (1948). Lernaeocera branchialis. Cellulae 52, 159-212.

Chrásková, J., Kaminsky, Y. and Krekule, I. (1999). An automatic 3D tracking system with a PC and a single TV camera. Fournal of Neuroscience Methods 88, 195-200.

De Beauchamp, P. (1952). Un facteur de la variabilité chez les rotifées du genre Brachionus. Comptes Rende de l'Académie des Sciences 234, 573-575.

De Meeus, T., Marin, R. and Renaud, F. (1992). Genetic heterogeneity within populations of Lepeophtheirus europaensis (Copepoda: Caligidae) parasitic on two host species. International fournal for Parasitology 22, 1179-1181.

Devine, G., Ingvarsdottir, A., Mordue, W., Pike, A., Pickett, J., Duce, I. and Mordue, A. (2000). Salmon lice, Lepeophtheirus salmonis, exhibit specific chemotactic responses to semiochemicals originating from the salmonid, Salmo salar. Fournal of Chemical Ecology 26, 1833-1848.

Doall, M. H., Colin, S. P., Strickler, J. R. and Yen, J. (1998). Locating a mate in 3D: the case of Temora longicornis. Philosophical Transactions of the Royal Society London, B 353, 681-689.

Doving, K. B., Westerberg, H. and Johnsen, P. B. (1985). Role of olfaction in the behavioural and neuronal responses of Atlantic salmon, Salmo salar, to hydrographic stratification. Canadian Fournal of Fisheries and Aquatic Science 42, 1658-1667.

Dutil, J. D. and Coutu, J.M. (1988). Early marine life of the Atlantic salmon, Salmo salar, post smolts in the northern Gulf of St. Lawrence. Fisheries Bulletin US 86, 197-212.

Fraile, L., Escoufier, Y. and Raibaut, A. (1993). Analyse des correspondances de données planifiées: etude de la chémotaxie de la larvae infestante d'un parasite. Biometrics 49, 1142-1153.

Halley, J. M., Hartley, S. and Kallimanis, A. S. (2004). Uses and abuses of fractal methodology in ecology. Ecology Letters 7, 254-271.

Heuch, P. A. (1995). Experimental evidence for aggregation of salmon louse copepodids (Lepeophtheirus salmonis) in step salinity gradients. Fournal of the Marine Biological Association of the UK 75, 927-939.

Heuch, P. A., Doall, M. H. and Yen, J. (2007). Water flow around a fish mimic attracts a parasitic and deters a planktonic copepod. Fournal of Plankton Research 29, i3-i16.

Heuch, P. A. and Karlsen, H. E. (1997). Detection of infrasonic water oscillations by copepodids of Lepeophtheirus salmonis (Copepoda: Caligidae). Journal of Plankton Research 19, 735-747. 
Heuch, P. A., Parsons, A. and Boxaspen, K. (1995). Diel vertical migration: a possible host-finding mechanism in salmon louse (Lepeophtheirus salmonis) copepodids? Canadian Fournal of Fisheries and Aquatic Science 52, 681-689.

Holm, M., Huse, I., Waatevik, E., Doving, K. B. and Aure, J. (1982) Behaviour of Atlantic salmon smolts during seaward migration. I. Preliminary report on ultrasonic tracking in a Norwegian fjord. C.M. 1982/M:7. ICES, Copenhagen, Denmark.

Ingvarsdottir, A., Birkett, M., Duce, I., Genna, R., Mordue, W., Pickett, J., Wadhams, L. and Mordue, A. (2002). Semiochemica strategies for sea louse control: host location cues. Pest Management Science 58, 537-545.

Kabata, Z. (1979). Parasitic Copepoda of British Fishes. Ray Society, London, UK.

Khan, R. A., Lee, E. M. and Barker, D. (1990). Lernaeocera branchialis: a potential pathogen to cod ranching. Fournal of Parasitology 76, 913-917.

Lewis, A. G. (1963). Life history of the caligid copepod Lepeophtheirus dissimulatus, Wilson, 1905. Pacific Science 17, 195-242.

Loehle, C. (1990). Home range: a fractal approach. Landscape Ecology 5, 39-52.

MacKinnon, B. M. (1993). Response of the copepod larvae of Caligus elongatus to light, and the ultrastructure of the eyes. Canadian Fournal of Fisheries and Aquatic Science 50, 793-799.

Murlis, J., Elkinton, J. S. and Cardé, R. T. (1992). Odor plumes and how insects use them. Annual Review of Entomology 37, 505-532.

Moore, P. and Crimaldi, J. (2004). Odor landscapes and animal behavior: tracking odor plumes in different physical worlds. Fournal of Marine Systems 49, 55-64.

Øines, Ø. and Heuch, P. A. (2005). Identification of sea louse species of the genus Caligus using mtDNA. Fournal of the Marine Biological Association of the UK 85, 73-79.

Olsen, R.S. (2001). Lepeophtheirus salmonis: mechanisms for host identification. $\mathrm{PhD}$ thesis, University of Bergen, Bergen, Norway.

Pike, A. W., Mordue, A. J. and Ritchie, G. (1993). The development of Caligus elongatus Nordmann from hatching to copepodid in relation to temperature. In Pathogens of Wild and Farmed Fish: Sea Lice (ed. Boxshall, G. A. and Defaye, D.), pp. 51-60. Ellis Horwood, Chichester, UK.

Ross, N. W., Firth, K. J., Wang, A., Burka, J. F. and Johnson, S. C. (2000). Changes in hydrolytic enzyme activities of naive Atlantic salmon Salmo salar skin mucus due to infection with the salmon louse Lepeophtheirus salmonis and cortisol implantation. Diseases of Aquatic Organisms 41, 43-51.
Rittschof, D. and Cohen, J. H. (2004). Crustacean peptide and peptidelike pheromones and kairomones. Peptides 25, 1503-1516.

Sandau, K. and Kurz, H. (1996). Measuring fractal dimension and complexity-an alternative approach with an application. Fournal of Microscopy 186, 164-176.

Schmitt, F. G, Seuront, L., Hwang, J-S., Souissi, S. and Tseng, L-C. (2006). Scaling of swimming sequences in copepod behaviour: data analysis and simulation. Physica A 364, 287-296.

Schuurmans Stekhoven, J.H. (1936). Copepoda parasitica from the Belgian coast, II. (Including some habitats in the North Sea). Memoires du Musée Royal d'Histoire Naturelle de Belgique 74, 1-20.

Scott, A. (1901). Lepeophtheirus and Lernaea. Liverpool Marine Biology Committee Memoirs 6, 54 pp.

Seuront, L., Hwang, J. S. and Tseng, L. C. (2004). Individual variability in the swimming behaviour of the sub-tropical copepod Oncaea venusta (Copepoda: Poecilostomatoida). Marine Ecology Progress Series 283, 199-217.

Sproston, N. G. (1942). The developmental stages of Lernaeocera branchialis. Fournal of the Marine Biological Association of the UK 25 441-446.

Sreenivasan, K. R., Prasad, R. R. and Menavau, C. (1989). The fractal geometry of interfaces and the multifractal distribution of dissipation in fully turbulent flows. In Fractals in Geophysics (ed. Scholz, C. H. and Mandelbrot, B. B.), pp. 43-60. Birkäuser, Basel, Switzerland.

Staaterman, E., Paris, C. B. and Helgers, J. (2012). Orientation behaviour in fish larvae: a missing piece to Hjort's critical period hypothesis. Fournal of Theoretical Biology 304, 188-196.

Tiselius, P. and Jonsson, P. R. (1990). Foraging behaviour of six calanoid copepods: observations and hydrodynamic analysis. Marine Ecology Progress Series 66, 23-33.

Turchin, P. (1996). Fractal analyses of animal movement: a critique. Ecology 77, 2086-2090.

Uttieri, M., Nihongi, A., Mazzocchi, M. G., Strickler, J. R. and Zambianchi, E. (2007). Pre-copulatory swimming behaviour of Leptodiaptomus ashlandi (Copepoda: Calanoida): a fractal approach. Fournal of Plankton Research 29, i17-i26.

Westerberg, H. (1982). Ultrasonic tracking of Atlantic salmon (Salmo salar L.) I. Movements in coastal regions. Report of the Institute of Freshwater Research Drottningholm 60, 81-101.

Wijesekera, H.W. (1996). Fractal dimension as an indicator for turbulent mixing in the thermocline. Fournal of Geophysical Research 101 703-709. 